\title{
O poeta da revolução
}

Adílson Odair Citelli

Professor Livre-Docente no Departamento de Comunicação e Artes da ECA-USP.

Chefe do Departamento de Comunicações e Artes.

E-mail: citelli@uol.com.br

O poeta, dramaturgo, agitador cultural Vladmir Maiakovski nasceu em 7 de julho de 1893 no pequeno lugarejo de Bagdadi, na Geórgia. Produziu uma das mais significativas obras poéticas do nosso tempo. Engajado desde o primeiro momento na revolução russa de 1917, seria um dos líderes da renovação literária e artística na recém-criada URSS. Inspirado nas posições futuristas e cubofuturistas, procurou integrar novas formas de composição poética aos temas com os quais trabalhava. Ao final entrou em choque com as posições stalinistas que predicavam uma arte de cunho naturalista, de pouca capacidade inventiva. Com a máxima "não há conteúdo revolucionário sem forma revolucionária", Maiakovski sinalizou com um tipo de criação em dissonância com o caráter panfletário que tomou conta da arte soviética no período. Suicidou-se em Moscou no dia 14 de abril de 1930. Tinha 37 anos.

\section{A PLENOS PULMÕES ${ }^{1}$}

Primeira Introdução ao Poema

Caros

camaradas

futuros!

Revolvendo

.a merda fóssil

$$
\text { de agora, }
$$

estes dias escuros,

$$
\text { .perscrutando }
$$

talvez

$$
\text { perguntareis }
$$

.por mim.

Ora,

começará

.vosso homem de ciência,

afagando os porquês

.num banho de sabença,

conta-se

.que outrora

um férvido cantor

a água sem fervura

combateu com fervor(1).

1. Campos H.A.; SCHNAI-

DERMAN, B. Maiakovski - poemas. São Paulo: Perspectiva. 1982. 
Professor,

.jogue fora

A mim cabe falar

.de mim

.de minha era.

$\mathrm{Eu}$ - incinerador,

.eu - sanitarista,

a revolução

.me convoca e me alista.

Troco pelo front

.a horticultura airosa

Ela ajardina o jardim virgem

$$
\text { da poesia - }
$$

.fêmea caprichosa.

.vargem

sombra

"É assim o jardim de jasmim,

.alfombra.

.o jardim de jasmim do alfenim."

Este verte versos feito regador,

boca em babador, aquele os baba,

.bonifrates encapelados,

entendê-los, descabelados vates -

ao diabo!,

.quem há-de...

Quarentena é inútil contra eles

- mandolinam por detrás das paredes:

"Ta-ran-tin, ta-ran-tin,

$$
\text { .ta-ran-ten-n-n..." }
$$

Triste honra,

$$
\text { se de tais rosas }
$$

$$
\text { minha estátua se erigisse: }
$$

na praça

.escarra a tuberculose;

putas e rufiões

.numa ronda de sífilis.

Também a mim

.a propaganda

é tão fácil

cansa,

.alinhavar

Mas eu

$$
\text { .romanças, - }
$$

.me dominava

e pisava

.entretanto

.a garganta do meu canto. 
Escutai,

o cáustico caudilho,

camaradas futuros,

o agitador,

o extintor

.dos melífluos enxurros:

por cima

dos opúsculos líricos,

.eu vos falo

.como um vivo aos vivos.

Chego a vós,

à Comuna distante, não como Iessiênin,

Mas através

guitarriarcaico.

.dos séculos em arco

.sobre os poetas

e sobre os governantes.

Meu verso chegará,

.não como a seta

lírico-amável,

Nem como

que persegue a caça.

ao numismata

.a moeda gasta,

.nem como a luz

Meu verso

.das estrelas decrépitas.

.com labor

.rompe a mole dos anos,

.a olho nu,

e assoma

.palpável,

bruto,

chega o aqueduto

.como a nossos dias

levantado

por escravos romanos.

No túmulo dos livros,

.versos como ossos,

se estas estrofes de aço

acaso descobrirdes,

.vós as respeitareis,

de um arsenal antigo,

como quem vê destroços

.mas terrível.

Ao ouvido

não diz

blandícias

minha voz; 
lóbulos de donzelas

de cachos e bandós

não faço enrubescer

.com lascivos rondós.

Desdobro minhas páginas

.- tropas em parada,

e passo em revista

Estrofes estacam

.o front das palavras.

.chumbo-severas,

.prontas para o triunfo

ou para a morte.

Poemas-canhões, rígida coorte,

apontando

as maiúsculas

.abertas.

Ei-la,

.a cavalaria do sarcasmo, minha arma favorita,

Rimas em riste, .alerta para a luta.

sofreando o entusiasmo, .eriça

E todo

suas lanças agudas.

este exército aguerrido, .vinte anos de combates,

não batido,

.eu vos dôo,

cada folha

$$
\text { proletários do planeta, }
$$

$\mathrm{O}$ inimigo

até a última letra.

da colossal

.classe obreira,

$$
\text { é também }
$$

meu inimigo

.figadal.

Anos

de servidão e de miséria

$$
\text { .comandavam }
$$

.nossa bandeira vermelha.

Nós abríamos Marx

volume após volume,

.janelas

.de nossa casa

abertas amplamente,

mas ainda sem ler

saberíamos o rumo! 
onde combater,

de que lado,

Dialética, em que frente.

.não aprendemos com Hegel.

Invadiu-nos os versos

ao fragor das batalhas,

sob o nosso projétil, .quando,

debandava o burguês

Que essa viúva desolada,

$$
\text { que antes nos debandara. }
$$

$$
\text { - glória - }
$$

após os gênios,

se arraste

Morre,

$$
\text { .merencória. }
$$

.meu verso,

como um soldado

na lufada do assalto.

.anônimo

Cuspo

sobre o bronze pesadíssimo,

cuspo

sobre o mármore viscoso.

Partilhemos a glória, -

entre nós todos, -

o comum monumento:

o socialismo,

$$
\text { .forjado }
$$

$$
\text { na refrega }
$$

$$
\text { e no fogo. }
$$

Vindouros,

varejai vossos léxicos:

$$
\begin{aligned}
& \text { do Letes } \\
& \text { brotam letras como lixo - }
\end{aligned}
$$

"tuberculose",

"bloqueio",

Por vós,

$$
\text { "meretrício". }
$$

geração de saudáveis, .um poeta,

lambeu

$$
\text { com a língua dos cartazes, }
$$

os escarros da tísis.

A cauda dos anos

faz-me agora

um monstro,

fossilcoleante. 
comunicação \& educação • Ano X • Número 3 - set/dez 2005

Camarada vida,

vamos,

para diante,

galopemos

pelo qüinqüênio afora(2).

Os versos

para mim

não deram rublos,

nem mobílias

de madeiras caras.

Uma camisa

lavada e clara,

e basta, -

para mim é tudo.

Ao Comitê Central

do futuro

ofuscante,

sobre a malta

dos vates

velhacos e falsários,

apresento

do registro partidário

.em lugar

todos

os cem tomos

dos meus livros militantes.

dezembro, 1929/janeiro, 1930.

1. Maiakovski escreveu versos de propaganda sanitária.

2. Alusão aos Planos Qüinqüenais soviéticos.

(Tradução e notas de Haroldo de Campos.) 